\section{EREM 74/2}

Journal of Environmental Research, Engineering and Management Vol. 74 / No. 2 / 2018 pp. $15-22$ DOI 10.5755/j01.erem.74.2.20615 (c) Kaunas University of Technology
Pollution of Small Kaunas Rivers with Biogenic Compounds and Heavy Metals

Received 2018/04
Accepted after revision 2018/09

\title{
Pollution of Small Kaunas Rivers with Biogenic Compounds and Heavy Metals
}

\section{Giedrè Kacienè}

Lithuania, Vytautas Magnus University, Department of Environmental Sciences. Vileikos st. 8, Kaunas

\section{Nazim Nikiforov}

The Kazakhstan Republic, North-Kazakhstan State University named after M. Kozybaev, Department of Geography and Ecology, Abay st.,9. Petropavlovsk, Kazakhstan

Corresponding author: giedre.kaciene@vdu.lt

G. Kacienè, Vileikos st. 8-125, LT 44404, Kaunas, Lithuania

The pollution of surface water bodies with biogenic compounds and heavy metals is a serious global concern for environment as well as for human health. Therefore, the aim of this study was to investigate the pollution of secondary rivers of Nemunas, flowing in Kaunas city, with respect to concentrations of biogenic nitric and phosphorus compounds as well as heavy metals in water and bottom sediments of the rivers. The samples of water and bottom sediments were taken in the influxes of Sèmena, Girstupis, Marvelè, Vežpienis and Veršvas. The concentrations of inorganic nitric compounds (ammonium, nitrites and nitrates), and phosphates as well as heavy metals ( $\mathrm{Zn}$ and $\mathrm{Cu}$ ) in water and bottom sediments were investigated. Semena was found to be the cleanest river, as its ecological status class varied from high (with respect to phosphates) to moderate (with respect to ammonium). Girstupis was highly polluted with phosphates; however, it showed a relatively good ecological status class with respect to nitric compounds. High concentration of phosphates was also found in Veršvas; however, contrary to Girstupis, this river contained exceptionally high concentration of reduced nitric compounds (ammonium). Véžpienis and Marvelè were the most polluted rivers, with most of the nitric and phosphorus compounds exceeding the limit values set in the wastewater management regulations. These rivers were attributed to the poor or bad ecological status class with respect to ammonium and the good or moderate ecological status class with respect to nitrates and/or phosphates. The concentrations of $\mathrm{Zn}$ were relatively low in the investigated Kaunas rivers; however, the concentration of Cu was found to be almost 3-times higher than the limit value in Sèmena, Girstupis and Veršvas.

Keywords: urban river pollution, heavy metals, nitric compounds, phosphates. 


\section{Introduction}

Urban river pollution is typically understood as a problem of the modern age. Scientists investigate two main aspects of river pollution: how by-products of industrial and agricultural run-off contaminate waterways, prompting legislative responses (Oosthoek, 2002; Massard-Guilbaud, 2004); and how domestic wastewater disposal creates hygiene concerns and difficulties with providing clean drinking water (Barles and Lestel, 2007; Closmann, 2007).

Pollutant discharge causes widespread organic and toxic pollution, as well as excess of biogenic nitric and phosphorus compounds, leading to eutrophication and severe ecological destruction (Miao et al., 2012). Biogeochemical cycles of phosphorus and nitrogen, which are important biogenic elements that determine the productivity and structural as well as functional organization of ecosystems, are currently undergoing significant anthropogenic transformations. One of the significant types of anthropogenic interference in the circulation of biogenic elements is the use of mineral fertilizers, in particular the ones containing nitrogen and phosphorus (Копла-Дикс and Старвинская, 1993). Another source of anthropogenic $\mathrm{N}$ and $\mathrm{P}$ compounds (and phosphates) is a discharge of partly treated wastewater (Chesterikoff et al., 1992; Sitonyte and Kerienè, 2010; Vrzel et al., 2016). The process of eutrophication of land-based reservoirs was ranked first in terms of the degree of danger of a global anthropogenic impact on the environment at the $22^{\text {nd }}$ Session of UNEP as early as in 1984. Eutrophication of water bodies is becoming one of the most urgent problems of surface water nowadays (Wang et al., 2012).

Toxic pollution of water bodies is determined by the presence of toxic compounds, in particular, heavy metal compounds. Heavy metals, such as arsenic, cadmium, chromium, copper, lead, mercury, nickel and zinc, polluting and accumulating in the water bodies present a rapidly growing global concern (Ахметшиева, 2015). These elements can be found in the environment (water reservoirs, the atmosphere and soil) in excess due to various anthropogenic activities. It is also important to note the natural sources of heavy metal pollution. These include weathering and erosion of all types of rocks (igneous, sedimentary and metamorphic), leading to liberation of various heavy metals, its transport and redistribution in the environment (Carpenter, 1998).

The pollution of surface water with biogenic compounds and heavy metals is a serious global concern for environment, as well as for human health. Overabundance of these elements poses severe health risks for humans, and for other life forms through bioaccumulation through food chains. Pollution of small urban water bodies is a widespread problem (Paul and Meyer, 2001; Ellis and Butler, 2015; Revitt and Ellis, 2016); however, there is a lack of data describing the quality and the specific pollution sources of freshwaters in urban areas (McGoff et al., 2017). Therefore, the aim of this study was to investigate the pollution of secondary rivers of Nemunas, flowing in Kaunas city, with respect to concentrations of biogenic nitric and phosphorus compounds as well as heavy metals in water and bottom sediments of the rivers.

\section{Methods}

\section{Research object and sampling}

The following investigated rivers are the secondary rivers of Nemunas, the biggest river in Lithuania (arranged in downstream order): Semena (left inflow), Girstupis (right inflow), Marvelè and Vèžpienis (left inflows) and Veršvas (right inflow) (Fig. 1) All these rivers are relatively small, belonging to the 1st type (catchment area $<100 \mathrm{~km}^{2}$ ) (Ministry of Environment, 2007) and flow through different regions of Kaunas city. The samples of water and bottom sediments were taken in December 2017 and January 2018 in the influxes of the investigated rivers (except Girstupis, where samples were taken immediately before the underground channelized part of the river) (Fig. 1). Water quality of the investigated rivers was assessed on the basis of EU and Lithuanian legislation. The rivers were assessed to one of the five ecological 
status classes (high, good, moderate, poor and bad) according to concentrations of nutrients (ammonium, nitrates and phosphates) and heavy metal micronutrients ( $\mathrm{n}$ and $\mathrm{Cu}$ ) (Table 1) (Ministry of Environment, 2007). Assessment of water quality according to the ecological status classes requires at least 4 seasonal measurements per year. This study, however, is only the beginning of longer investigation, revealing the fact of pollution of small Kaunas rivers and the need of continuous survey of water quality in it. In order to compare the water quality of the investigated streams with other bigger Lithuanian rivers, the concentrations of nitric compounds and phosphates were compared with the limit values set in the wastewater management regulations of Lithuania (Ministry of Environment, 2006). Although the investigated rivers are not official sewage receivers, some of them (Semena, Girstupis, Veršvas and Marvelè) are used for collecting surface run-off. Moreover, some collectors of surface run-off are also used for collecting the sewage

\section{Fig. 1}

The sampling places in the secondary rivers of Nemunas in Kaunas (1 - Sèmena, 2 - Girstupis, 3 - Marvelè, 4 - Vežzienis, 5 - Veršvas)
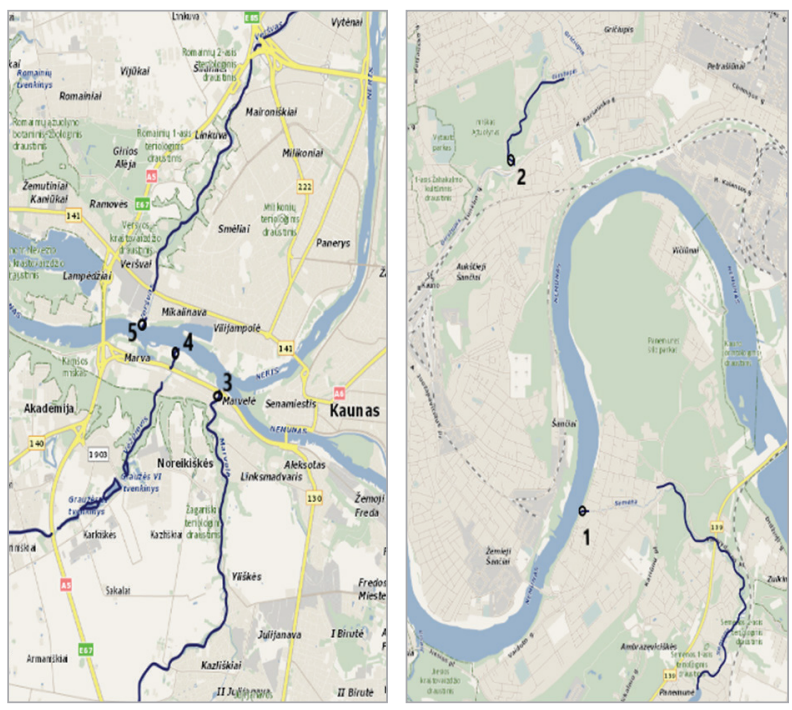

from individual residential houses (Municipality Administration of Kaunas City, 2010).

The water samples were stored at $-30^{\circ} \mathrm{C}$ before analysis. The samples of bottom sediments were dried in electric oven 3 days at $80^{\circ} \mathrm{C}$, sieved through a $2-\mathrm{mm}$ sieve, grounded with a mortar and stored at room temperature before analysis.

\section{Chemical Analysis}

\section{Determination of concentrations of phosphates and nitric compounds}

Concentrations of phosphates and inorganic nitric compounds - ammonium, nitrites and nitrates - were investigated spectrophotometrically according to Bartoshova et al. (2012) with minor corrections. The concentration of ammonium was detected by reaction of ammonium ion with Nessler. Water sample was mixed with Segnet salt and Nessler reagent, light absorption was measured at $400 \mathrm{~nm}$. The concentration of nitrites was determined by reaction with sulphanilamide. Colour development was measured at $540 \mathrm{~nm}$. For determination of the concentration of nitrates, a diluted water sample was mixed with sodium salicylate and evaporated in a sand bath at $100^{\circ} \mathrm{C}$. Light absorption was measured after precipitates' reaction with sulphuric acid and alkaline solution of tartrate at $420 \mathrm{~nm}$. The concentration of phosphates was determined according to the production of a blue complex phosphorus and molybdenum compound after reaction with antimony salt and reduction with ascorbic acid. Light absorption was measured at $670 \mathrm{~nm}$.

\section{Determination of concentration of heavy metals}

The mineralization of the sediment sample was performed according to the manufacturer's instructions. The sample was mixed with the following acids: concentrated acetic acid, hydrochloric acid and hydrofluoric acid, as well as $5 \%(\mathrm{w} / \mathrm{v})$ boric acid. The mixture was digested using High Performance Digestion System Ethos One (Milestone Helping Chemists, JAV) until full mineralization of the sample. The concentration of $\mathrm{Zn}$ and $\mathrm{Cu}$ in the diluted acidic solution of the sample was detected with atomic absorption spectrometer AA-6800 (Shimadzu, Japan).

\section{Statistical analysis}

All measurements were performed in five replicates. The data were analyzed using STATISTICA 8 software and Student's t test at $p<0.05$. 


\section{Results and Discussion}

\section{Concentration of biogenic $\mathrm{N}$ and $\mathrm{P}$ compounds}

The concentration of biogenic nitric compounds in the secondary rivers of Nemunas is shown in Fig. 2. The investigated rivers contained relatively high concentrations of ammonium, nitrites and/or nitrates, as in many cases the concentrations of these compounds were close to or even exceeded the limit values, set in the wastewater management regulations (Ministry of Environment, 2006). The highest concentrations of ammonium were found in Véžpienis and Veršvas (8.2 $\mathrm{mg} / \mathrm{L}$ and $8.6 \mathrm{mg} / \mathrm{L} \mathrm{L}$ respectively), exceeding the limit value of $1 \mathrm{mg} / \mathrm{L}$ by approximately 8.3 times. Such high concentrations are rarely determined even in urban rivers. For example, a similar level of $\mathrm{NH}_{4}{ }^{+}-\mathrm{N}$ was detected only in the surface water outfalls, polluted by sewage in the suburbs of London (Ellis and Butler, 2015). Attention should be paid to the fact that the lowest concentration of $\mathrm{NH}_{4}^{+}-\mathrm{N}(0.12 \mathrm{mg} / \mathrm{L})$ was detected in Girstupis. This fact evidences the ecological role of Mickevičius valley for self-purification of this river before entering the underground channel and the main River Nemunas, as the park is located in the middle part of Girstupis, above the underground channelized part and the water sampling point of this river. According to ammonium concentration, Girstupis was attributed to the rivers of the good ecological status class, Semena to moderate, Marvele to poor, Vežpienis and Veršvas to the bad ecological status class (Ministry of Environment, 2007).

The highest concentration of nitrites was detected in Vezžpienis river $(0.093 \mathrm{mg} \mathrm{N} / \mathrm{L})$, exceeding the limit value $(0.03 \mathrm{mg} \mathrm{N} / \mathrm{L})$ approximately by 3 -times $(\mathrm{p}<0.05)$. A high level of $\mathrm{NO}_{2}^{-}-\mathrm{N}$ was also observed in Semena and Marvelè, whereas other investigated rivers contained a relatively low level of this $\mathrm{N}$ compound (Fig. 2).

The highest concentration of nitrates was found in Marvele $(3.8 \mathrm{mg} \mathrm{N} / \mathrm{L})$. The concentration of nitrates was lower than the limit value $(2.3 \mathrm{mg} \mathrm{N} / \mathrm{L})$ in other rivers of Kaunas, fluctuating from $0.4 \mathrm{mg} \mathrm{N} / \mathrm{L}$ in Veršvas to $1.9 \mathrm{mg} \mathrm{N} / \mathrm{L}$ in Véžpienis. In the latter case the concentration of nitrates was close to the limit value, set in the wastewater management regulations
Fig. 2

The concentration of ammonium and nitrites in the secondary rivers of Nemunas in Kaunas city

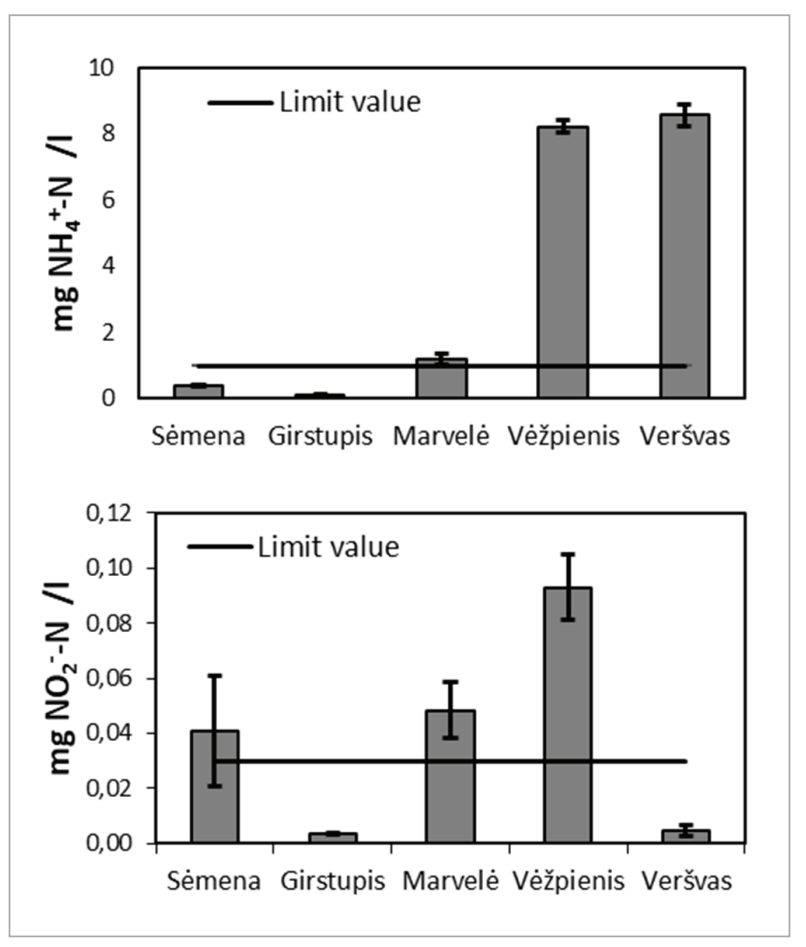

(Ministry of Environment, 2006) and did not differentiate from it statistically significantly. A similar level of $\mathrm{NO}_{3}{ }^{-}-\mathrm{N}$ was also detected in urban streams in London (McGoff et al., 2017) and in Spanish rivers with low agricultural intensity in catchments areas (Moreno et al., 2006). The ecological status classes of the investigated rivers with respect to the concentration of nitrates were as follows: Girstupis and Veršvas - high, Sèmena and Vežpienis - good, Marvelè - moderate (Ministry of Environment, 2007) (Fig. 3).

Our study revealed that all the investigated rivers, except Semena, were polluted with phosphates. The concentrations of $\mathrm{PO}_{4}{ }^{3+}-\mathrm{P}$ were higher than the limit value $(0.0653 \mathrm{mg} P / L)$ in Girstupis and Marvele $(p<0.05)$, whereas the concentrations of phosphates in Věžpienis and Veršvas did not differ from it statistically significantly. According to the concentrations of phosphates, Semena should be attributed to the rivers of the high ecological status class, Vèžpienis, Veršvas and Marvele to the good ecological status class, and Girstupis to the moderate ecological status class 


\section{Fig. 3}

The concentration of phosphorus and nitrates in the secondary rivers of Nemunas in Kaunas city

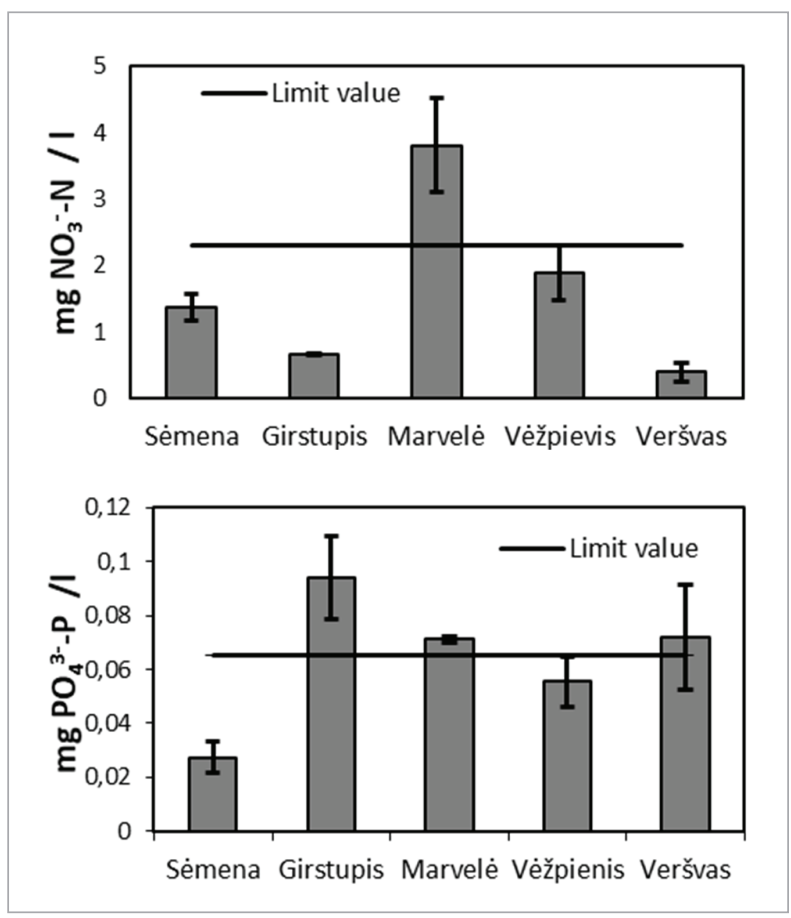

(Ministry of Environment, 2007) (Fig. 3). On the other hand, the concentrations of $\mathrm{PO}_{4}{ }^{3+}-\mathrm{P}$ in both Girstupis and Marvele were above the limits, set for receiving waters in the wastewater management regulations (Ministry of Environment, 2006). High P concentrations correlate with urban use in catchment areas, industry and households being as the main sources of pollution (Moreno et al., 2006). Moreover, according to the Municipality Administration of Kaunas City, Kaunas district Aleksotas and the City centre, which are drained by Marvele and Girstupis, respectively, still have mixed sewerage, with some household sewage incorporated to surface run-off sewers (Municipality Administration of Kaunas City, 2010). Such sewerage might be the major reason of the relatively high concentrations of $\mathrm{PO}_{4}{ }^{3+}-\mathrm{P}$ in these rivers.

The concentration of ammonium and nitrates is climate-dependent and tends to be higher in the cold season, when consumption by plants and microorganisms is terminated and leaching from soil is the most intensive (Brett et al., 2005; Sitonyte and
Kerienè, 2010). Therefore, a relatively high level of these biogenic $\mathrm{N}$ compounds in the investigated rivers of Kaunas could be at least partly determined by the seasonal variation and is expected to be lower in spring and summer. On the other hand, concentration of phosphates follows the different pattern and reaches the highest level in summer (Brett et al., 2005; Sitonyte and Kerienè, 2010). Therefore, the results of the earlier studies suggest that an average annual level of $\mathrm{PO}_{4}{ }^{3}-\mathrm{P}$ in the investigated rivers of Kaunas might be even higher than determined during this survey. Since this study revealed that small Kaunas rivers are considerably polluted with biogenic compounds, further investigations, including at least 4 seasonal measurements annually, are needed in the future.

In summary of the results of the concentrations of biogenic $\mathrm{N}$ and $\mathrm{P}$ compounds in the secondary rivers of Nemunas, Sèmena should be distinguished as a relatively unpolluted river, as its ecological status class varied from high (with respect to phosphates) to moderate (with respect to ammonium). The catchment area of this river is mostly situated in wooded areas with low population density, leading to relatively low water pollution. Girstupis was highly polluted with phosphates; however, its ecological status class with respect to nitric compounds was good or even high. In contrast, Veršvas was highly polluted with reduced nitrogen (ammonium), indicating the pollution with sewage (Chesterifoff et al., 1992; Revitt and Ellis, 2016; Česonienè et al., 2017). Vèžpienis and Marvelè were found to be among the most polluted rivers in Kaunas, with most of the $\mathrm{N}$ and $\mathrm{P}$ compounds exceeding the limit values in the influxes of these rivers. Both rivers flow through urbanized suburb areas of Kaunas, some sections of them are channelized or dammed, limiting self-purification and increasing the risk of pollution with untreated or partly purified wastewater. Household sewage, entering the streams both accidentally or deliberately might be the major reason of their pollution. This presumption is based on the fact that about $10 \%$ of inhabitants of Kaunas city still do not have connections to municipal sewerage system (Municipality Administration of Kaunas City, 2010). This leads to surface water sewers misconnections (illicit discharges of wastewater into surface water 
sewerage), which is the widespread problem even in developed countries, such as the United States and the United Kingdom (Ellis and Butler, 2015).

\section{Heavy metals in water and bottom sediments}

The concentrations of heavy metals copper $(\mathrm{Cu})$ and zinc $(\mathrm{Zn})$ were investigated in the water and sediments of secondary rivers of Nemunas, in Kaunas city (Table 2). Our study has shown that concentration of $\mathrm{Zn}$ in water was relatively low and did not exceed the limit value $100 \mu \mathrm{g} / \mathrm{L}$ (Ministry of Environment 2006). The average $\mathrm{Zn}$ concentration in Semena and Véžpienis was $15.5 \mu \mathrm{g} / \mathrm{L}$, whereas $\mathrm{Zn}$ concentration was below the detection limit in Girstupis, Marvele and Veršvas. In contrast to zinc, the level of Cu in Semena, Girstupis and Veršvas exceeded the limit value of $10 \mu \mathrm{g} / \mathrm{L}$ (Ministry of Environment, 2006) almost 3 times. Cu concentration in the bottom sediments of the investigated rivers was also higher than $\mathrm{Zn}$. The highest concentration was found in Girstupis $(20 \mu \mathrm{g} / \mathrm{g})$, whereas in other rivers it varied from $3.7 \mu \mathrm{g} / \mathrm{g}$ (in Marvelè) to 7 $\mu \mathrm{g} / \mathrm{g}$ (in Véžpienis). The rivers are attributed to the good or moderate ecological status class with respect to pollution with $\mathrm{Zn}$ or $\mathrm{Cu}$, if concentration of these heavy metals is lower or higher than $20 \mu \mathrm{g} / \mathrm{L}$ or $5 \mu \mathrm{g} / \mathrm{L}$, respectively (Table 1 ) (Ministry of Environment, 2007). Therefore, all the investigated rivers (except Marvele) were in the moderate ecological status class according to the concentration of $\mathrm{Cu}$. In contrast, good water quality with respect to $\mathrm{Zn}$ was characteristic of the investigated streams (Table 2). Cu and Zn

\section{Table 2}

The concentration of heavy metals (HM) in water and the bottom sediments of the investigated rivers

\begin{tabular}{l|c|c|c|c}
\hline \multirow{2}{*}{ River } & \multicolumn{2}{|c|}{$\mathrm{HM}$ in water $\mu \mathrm{g} / \mathrm{L}$} & \multicolumn{2}{c}{$\mathrm{HM}$ in bottom sediments $\mu \mathrm{g} / \mathrm{g}$} \\
\cline { 2 - 5 } & $\mathrm{Zn}$ & $\mathrm{Cu}$ & $\mathrm{Zn}$ & $\mathrm{Cu}$ \\
\hline Sèmena & 2 & 3 & 4 & 5 \\
\hline Girstupis & n.d. & 29 & n.d. & 20.06 \\
\hline Marvelè & n.d. & 2 & 0.221 & 3.69 \\
\hline Veršvas & n.d. & 28 & 3.977 & 2.99 \\
\hline Vèžpienis & 15 & 7 & 0.693 & 6.99 \\
\hline Limit value & 100 & 10 & & \\
\hline
\end{tabular}

are among the most prevalent heavy metals in urban rivers, entering the water bodies mostly via non-point sources, such as surface run-off from roads and parking lots (Paul and Meyer, 2001). Our study showed that the bottom sediments of the investigated rivers contained a relatively low amount of $\mathrm{Zn}$ and $\mathrm{Cu}$ (with exception of $\mathrm{Cu}$ in the bottom sediments of Girstupis) (Table 2). A relatively high concentration of $\mathrm{Cu}$ in Girstupis sediments might be explained by lower water velocity and a higher amount of silt in the bottom of this stream, as fine particles and organic matter have the highest metal adsorption potential (Paul and Meyer, 2001). The research conducted by Žaltauskaitè (2013) demonstrated much higher concentrations of $\mathrm{Zn}, \mathrm{Cu}, \mathrm{Ni}$ and $\mathrm{Pb}$ in the rivers of Kaunas (Semena,

Table 1

The ecological status classes of the rivers according to the physico-chemical quality parameters (Ministry of Environment, 2007

\begin{tabular}{l|c|c|c|c|c}
\hline \multirow{2}{*}{$\begin{array}{c}\text { Physico-chemical quality } \\
\text { parameter }\end{array}$} & \multicolumn{5}{|c}{ Ecological status class } \\
\cline { 2 - 5 } & High & Good & Moderate & Poor & Bad \\
\hline $\mathrm{NO}_{3}-\mathrm{N}, \mathrm{mg} / \mathrm{L}$ & 2 & 3 & 4 & 5 & $>10.00$ \\
\hline $\mathrm{NH}_{4}{ }^{+}-\mathrm{N}, \mathrm{mg} / \mathrm{L}$ & $<1.30$ & $1.30-2.30$ & $2.31-4.50$ & $4.51-10.00$ & $>1.50$ \\
\hline $\mathrm{PO}_{4}{ }^{3+}-\mathrm{P}, \mathrm{mg} / \mathrm{L}$ & $<0.10$ & $0.10-0.20$ & $0.21-0.60$ & $0.61-1.50$ & $>0.40$ \\
\hline $\mathrm{Zn}, \mu \mathrm{g} / \mathrm{L}$ & $<0.05$ & $0.05-0.09$ & $0.091-0.18$ & $0.181-0.04$ & \\
\hline $\mathrm{Cu}, \mu \mathrm{g} / \mathrm{L}$ & & $\leq 20$ & $>20$ & & \\
\hline
\end{tabular}


Vezžpienis, Girstupis, Marvele), varying in the range of $10-65 \mu \mathrm{g} / \mathrm{g}$. These findings emphasize the necessity of further investigations of Kaunas streams.

\section{Conclusions}

Small secondary rivers of Nemunas in Kaunas city were differently polluted with phosphates and biogenic nitric compounds. Semena was found to be the cleanest river, as its ecological status class varied from high (with respect to phosphates) to moderate (with respect to ammonium). Girstupis was highly polluted with phosphates; however, it showed the good ecological status class with respect to nitric compounds. High

\section{References}

Barles S., Lestel L. (2007). The nitrogen question: Urbanization, industrialization, and river quality in Paris, 18301939. Journal of Urban History 33: 794-812. https://doi. org/10.1177/0096144207301421

Bartošová A., Michalíková A., Sirotiak M. et al. (2012). Comparison of Two Spectrophotometric Techniques for Nutrients Analyses in Water Samples. Research Papers Faculty of Materials Science and Technology in Trnava Slovak University of Technology in Bratislava 33: 8-19.

Brett M., Arhonditisis G. and Mueller S. (2005). Non-PointSource Impacts on Stream Concentrations Along a Forest to Urban. Environmental Management 35: 330-342. https://doi. org/10.1007/s00267-003-0311-z

Carpenter S., Caraco N., Correll D. et al. (1998). Nonpoint Polution of Surface Waters with Phosphorus and Nitrogen. Ecological Applications 8: 559-568. https://doi. org/10.1890/1051-0761(1998)008[0559:NPOSWW]2.0.CO;2

Česonienè L., Dapkienè M., Šileikienè D. et al. (2017). Impact of Wastewater Treatment Plant on Water Quality of the River Mažoji Sruoja, Plunge District. Journal of Environmental Research Engineering and Management 73(3): 33-44.

Chesterikoff A., Garban B., Billen G. et al. (1992). Inorganic nitrogen dynamics in the River Seine downstream from Paris (France), Biogeochemistry 17: 147-164. https://doi.org/10.1007/BF00004039

Closmann C. (2007). Chaos and contamination: water pollution and economic upheaval in Hamburg, 1919-1923. Urban History 33: 828-847. https://doi.org/10.1177/0096144207301453

Ellis J., Butler D. (2015). Surface Water Sewer Misconnections in concentration of phosphates was also found in Veršvas; however, contrary to Girstupis, this river contained an exceptionally high concentration of reduced nitric compounds (ammonium). Vèžpienis and Marvelè were the most polluted rivers, with most of the nitric and phosphorus compounds exceeding the limit values set for receiving waters in the wastewater management regulations. These rivers were attributed to the poor or bad ecological status class with respect to ammonium and to the good or moderate ecological status class with respect to nitrates and/or phosphates. The concentrations of $\mathrm{Zn}$ were relatively low in the investigated Kaunas rivers; however, the concentration of $\mathrm{Cu}$ was found to be almost 3-times higher than the limit value in Semena, Girstupis and Veršvas.

England and Wales: Pollution Sources and Impacts. Science of the Total Environment 526: 98-109. https://doi.org/10.1016/j. scitotenv.2015.04.042

Massard-Guilbaud G. (2004) Einspruch! Stadtbürger und Umweltverschmutzung im Frankreich des 19. Jahrhunderts. In: Bernhardt C (ed) Environmental problems in European cities in the 19th and 20th century. Waxmann, Münster, 67-86.

McGoff E., Dunn F., Cachazo L.M., et al. (2017). Finding Clean Water Habitats in Urban Landscapes: Professional Research vs Citizen Science Aproaches. Science of the Total Environment, 581 582: 105-116. https://doi.org/10.1016/j.scitotenv.2016.11.215

Miao Y., Fan C., \& Guo J. (2012). China's water environmental problems and improvement measures. Environmental \& Resource Economics 3: 43-44.

Ministry of Environment of Republic of Lithuania. Isakymas dèl nuoteku tvarkymo reglamento patvirtinimo (Order on the approval of wastewater management regulations) (2006). Available at: https://www.e-tar.lt/portal/lt/legalAct/TAR.4DODFCDD673A/GYdugGvOlU (In Lithuanian).

Ministry of Environment of Republic of Lithuania. Isakymas dèl paviršinių vandens telkinių būklès nustatymo metodikos patvirtinimo (Order on the approval of the methodology for determining the condition of surface water bodies) (2007). Available at: https://www.e-tar.lt/portal/lt/legalAct/TAR.881D6E973D28/ UkFdFqUMfe (In Lithuanian).

Moreno J., Navarno C. \& De las Heras J. (2006). Abiotic Ecotypes in South-Central Spanish Rivers: Reference Conditions and Pollution. Environmental Pollution 143: 388-396. https:// doi.org/10.1016/j.envpol.2005.12.012 
Municipality Administration of Kaunas City. Kauno miesto savivaldybės vandens tiekimo ir nuoteku tvarkymo infrastruktūros pletros specialusis planas (Special plan for the development of water supply and wastewater management infrastructure Municipality of Kaunas City) (2010). Available at: https://www. kaunovandenys.lt/SiteAssets/Files/Kauno_m_SP_sprendiniai_12-24.pdf (In Lithuanian).

Oosthoek J. (2002) The stench of prosperity. Water pollution in the northern Netherlands 1850-1980. In: Bernhardt C, Massard-Guilbaud $G$ (eds) Le démon moderne: La pollution dans les sociétés urbaines et industrielles d'Europe. Presses Universitaires Blaise-Pascal. Clermont-Ferrand: Presses Universitaires Blaise-Pascal, 179-194.

Paul M., Meyer J. (2001). Streams in the Urban Landscape. Annual Review of Ecology and Systematics 32, 333-365. https:// doi.org/10.1146/annurev.ecolsys.32.081501.114040

Revitt M., Eills B. (2016). Urban Surface Water Pollution Prob- lems Arising from misconnections. Science of the Total Environment 551-552: 163-174. https://doi.org/10.1016/j.scitotenv.2016.01.198

Sitonytè J., Kerienè I. (2010). Pollution of the River Venta within the Territory of Kuršenai Town. Journal of Environmental Research. Environmental Research, Engineering and Management 3(53): 5-12.

Vrzel J., Vukovich-Gachic B., Kolarevich S. et al (2016). Determination of the sources of nitrate and the microbiological sources of pollution in the Sava River Basin. Science of the Total Environment 573: 1460-1471. https://doi.org/10.1016/j.scitotenv.2016.07.213

Wang J., Liu X.D. \& Lua J. (2012). Urban River Pollution Control and Remediation. Science of the Total Environment 573: 1856-1862.

Žaltauskaitè J. (2013). Kauno mieste tekančių mažų upelių vandens kokybès jvertinimas (Assessment of Kaunas small streams waters quality). Žmogaus ir gamtos sauga, 133-136 (In Lithuanian).

\section{Kauno upelių užterštumas biogeniniais junginiais ir sunkiaisiais metalais}

\section{Gauta:} $2018 \mathrm{~m}$. balandis Priimta spaudai: $2018 \mathrm{~m}$. rugsèjis

\section{Giedrè Kacienè}

Vytauto Didžiojo universitetas, Aplinkotyros katedra, Lietuva

\section{Nazim Nikiforov}

Šiaurès Kazachstano universitetas, Geografijos ir Ekologijos katedra, Kazachstanas

Paviršinių vandens telkinių užterštumas biogeniniais junginiais ir sunkiaisiais metalais yra svarbi pasauliné aplinkos ir žmogaus sveikatos problema. Dèl šios priežasties šio tyrimo tikslas buvo ištirti Nemuno intaku, tekančiu per Kauno miestą, užterštumą biogeniniais azoto ir fosforo junginiais bei sunkiaisiais metalais. Vandens ir dugno substrato mėginiai buvo paimti Sèmenos, Girstupio, Marvelès, Věžpienio ir Veršvo upeliu žiotyse. Buvo jvertintos neorganinių azoto junginiu (amonio, nitritu ir nitratų), fosfaty ir sunkiuju metalu ( $\mathrm{Zn}$ ir Cu) koncentracijos vandenyje ir dugno nuosèdose. Nustatyta, kad Sèmena yra švariausias iš tirtų upelių, jo ekologinès būklès klase svyravo tarp labai geros (pagal fosfatu koncentraciją) ir vidutinès (pagal amonio koncentraciją). Girstupis buvo labai užterštas fosfatais, tačiau jo ekologinès būklès klase buvo gana aukšta remiantis azoto junginių koncentracijomis. Didelè fosfatų koncentracija taip pat buvo nustatyta ir Veršvo upelyje, tačiau, priešingai nei Girstupyje, šio upelio vandenyje taip pat buvo ir didelès redukuotu azoto junginiu (amonio) koncentracijos. Tyrimas parodè, kad Vežzievis ir Marvele yra labiausiai užteršti upeliai, daugelis N ir P junginių viršijo leistinas koncentracijas, nustatytas nuoteku tvarkymo reglamente. Šie upeliai buvo priskirti blogos arba labai blogos ekologinès būklès klasei pagal amonio koncentracijas ir vidutinès arba geros ekologinès būklès klasei pagal nitratu bei fosfatų koncentracijas. Cinko koncentracija tirtuose Kauno upeliuose buvo palyginti maža, tačiau vario koncentracija Sėmenos, Girstupio ir Veršvo upeliuose viršijo ribinę vertę apie 3 kartus.

Raktiniai žodžiai: miesto upių tarša, sunkieji metalai, azoto junginiai, fosfatai. 